\title{
Corpus callosum dysgenesis limits MRI changes to one hemisphere in status epilepticus
}

\section{Figure $1 \quad$ Unilateral seizure activity}

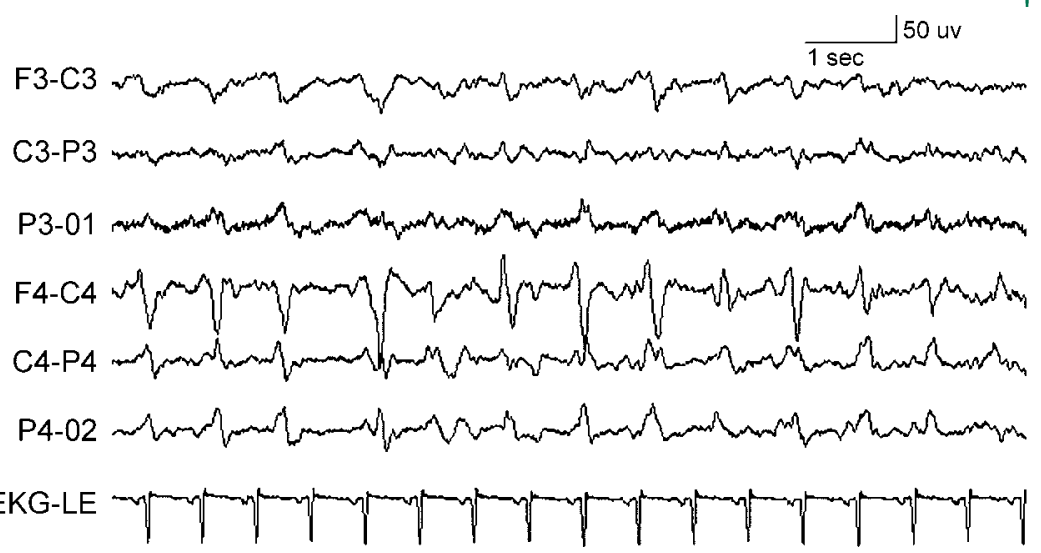

Bipolar longitudinal EEG montage demonstrates unilateral ictal activity in C4 and P4. Complete bipolar montage (figure e-1) and prolonged EEG recording (figure e-2) are available on the Neurology ${ }^{\circledR}$ Web site at www.neurology.org.

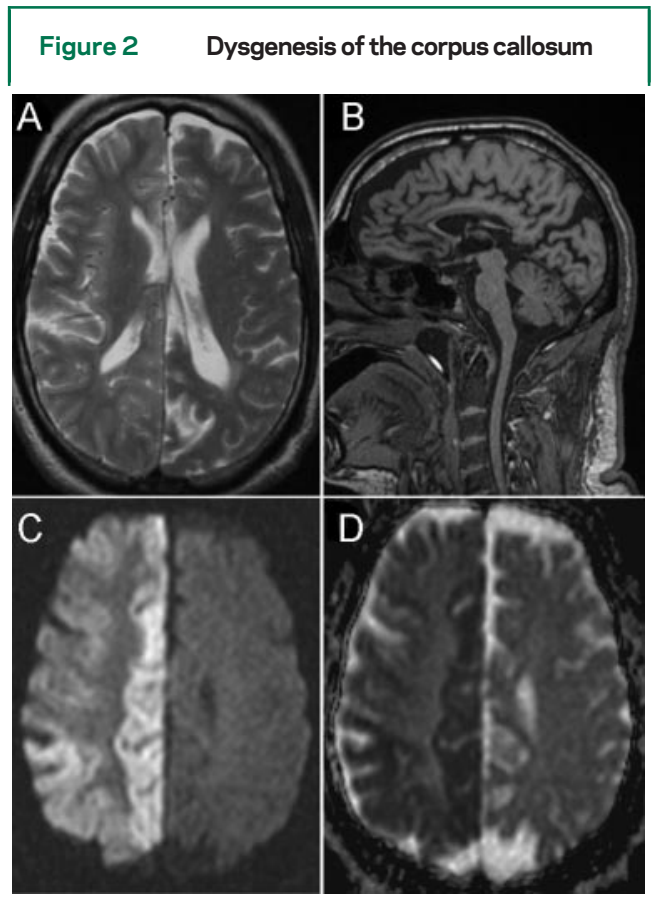

Axial T2 (A) and sagittal T1 (B) images demonstrate the dysgenesis of the corpus callosum. Diffusion-weighted imaging (C) and apparent diffusion coefficient (D) images show cytotoxic edema throughout the complete right cortex, corresponding with electroencephalographic status epilepticus.
Supplemental data at www.neurology.org
A 46-year-old man with cerebral palsy presented with complex partial seizures and left sided clonic movements. EEG showed right hemispheric seizures (figure 1). MRI demonstrated dysgenesis of the corpus callosum (figure 2, A and B) with hyperintense signal throughout the right cortex in diffusion-weighted imaging (DWI) (figure 2C) corresponding with decreased apparent diffusion coefficient signal (figure 2D). Gyriform cortical hyperintensities on DWI may occur during status epilepticus that do not respect vascular distributions. ${ }^{1,2}$ We suggest that DWI changes are restricted to one hemisphere because dysgenesis of the corpus callosum prohibits the spread of ictal activity to the contralateral hemisphere.

Christian Grommes, MD, Roger Oghlakian, MD, Kristina A. Blackham, MD, and Michael A. De Georgia, MD, Cleveland, $\mathrm{OH}$

Disclosure: The authors report no disclosures.

Address correspondence and reprint requests to Dr. Michael A. De Georgia, Department of Neurology, University Hospitals Case Medical Center, 11100 Euclid Avenue, Cleveland, OH 44106; Michael.DeGeorgia@uhhospitals.org

1. Wieshmann UC, Symms MR, Shorvon SD. Diffusion changes in status epilepticus. Lancet 1997;16:493-494.

2. Lansberg MG, O’Brien MW, Norbash AM, Moseley ME, Morrell M, Albers GW. MRI abnormalities associated with partial status epilepticus. Neurology 1999;52:1021-1027. 


\section{Neurology}

Corpus callosum dysgenesis limits MRI changes to one hemisphere in status epilepticus Christian Grommes, Roger Oghlakian, Kristina A. Blackham, et al.

Neurology 2009;72;942

DOI 10.1212/01.wnl.0000344186.12740.9a

\section{This information is current as of March 9, 2009}

\section{Updated Information \&} Services

Supplementary Material

\section{References}

\section{Citations}

Subspecialty Collections

Permissions \& Licensing

Reprints including high resolution figures, can be found at: http://n.neurology.org/content/72/10/942.full

Supplementary material can be found at: http://n.neurology.org/content/suppl/2009/03/09/72.10.942.DC1

This article cites 2 articles, 1 of which you can access for free at: http://n.neurology.org/content/72/10/942.full\#ref-list-1

This article has been cited by 1 HighWire-hosted articles: http://n.neurology.org/content/72/10/942.full\#\#otherarticles

This article, along with others on similar topics, appears in the following collection(s):

DWI

http://n.neurology.org/cgi/collection/dwi

EEG

http://n.neurology.org/cgi/collection/eeg_

MRI

http://n.neurology.org/cgi/collection/mri

Status epilepticus

http://n.neurology.org/cgi/collection/status_epilepticus

Information about reproducing this article in parts (figures,tables) or in its entirety can be found online at:

http://www.neurology.org/about/about_the_journal\#permissions

Information about ordering reprints can be found online:

http://n.neurology.org/subscribers/advertise

Neurology ${ }^{\circledR}$ is the official journal of the American Academy of Neurology. Published continuously since 1951, it is now a weekly with 48 issues per year. Copyright . All rights reserved. Print ISSN: 0028-3878. Online ISSN: 1526-632X.

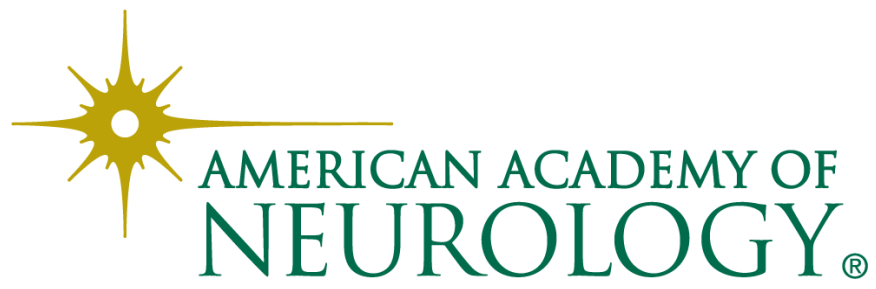

